\title{
Electrodialytic remediation of municipal solid waste incineration residues using different membranes
}

Parés Viader, Raimon; Jensen, Pernille Erland; Ottosen, Lisbeth M.

Published in:

Chemosphere

Link to article, DOI:

10.1016/j.chemosphere.2016.11.047

Publication date:

2017

Document Version

Peer reviewed version

Link back to DTU Orbit

Citation (APA):

Parés Viader, R., Jensen, P. E., \& Ottosen, L. M. (2017). Electrodialytic remediation of municipal solid waste incineration residues using different membranes. Chemosphere, 169, 62-68.

https://doi.org/10.1016/j.chemosphere.2016.11.047

\section{General rights}

Copyright and moral rights for the publications made accessible in the public portal are retained by the authors and/or other copyright owners and it is a condition of accessing publications that users recognise and abide by the legal requirements associated with these rights.

- Users may download and print one copy of any publication from the public portal for the purpose of private study or research.

- You may not further distribute the material or use it for any profit-making activity or commercial gain

- You may freely distribute the URL identifying the publication in the public portal

If you believe that this document breaches copyright please contact us providing details, and we will remove access to the work immediately and investigate your claim. 
3 Raimon Parés Viader ${ }^{\mathrm{a}^{*}}$, Pernille Erland Jensen ${ }^{\mathrm{a}}$, Lisbeth M. Ottosen ${ }^{\mathrm{a}}$

$4 \quad{ }^{a}$ Department of Civil Engineering, Technical University of Denmark, Building 118, 2800 Kongens Lyngby, Denmark

$5 \quad$ *Corresponding author: rapv@byg.dtu.dk, Tel: +4545252163

\section{Abstract}

7 In the present work, three different commercial membrane brands were used in an identical electrodialytic cell setup

8 and operating conditions, in order to reduce the leaching of metals and salt anions of two types of municipal solid waste

9 incineration residues: air pollution control residues of a semi-dry flue-gas cleaning system and fly ashes from a plant

10 with wet flue-gas cleaning system. The results showed a general reduction of the leaching in both residues after ED

11 remediation. For the following elements, the leaching was found to be different after ED treatment depending on the membrane used, with statistical significance:

- Air pollution control residues of the semi-dry flue-gas cleaning system: $\mathrm{Cr}, \mathrm{Cu}, \mathrm{Ni}, \mathrm{Pb}, \mathrm{Zn}$;

- Fly ashes from a plant with wet flue-gas cleaning system: $\mathrm{Al}, \mathrm{Ba}, \mathrm{Cu}, \mathrm{Ni}, \mathrm{Zn}, \mathrm{Cl}, \mathrm{SO}_{4}$.

Final leaching values for some elements and membranes, but not the majority, were below than those of certified coal fly ash (e.g. $\mathrm{Al}$ or $\mathrm{Cr}$ ), a material which is commonly used in construction materials; at the same time, some of these values were reduced to below the Danish law thresholds on the use of contaminated soil in constructions. These results show the potential of ED as a technology to upgrade municipal solid waste incineration residues.

Keywords: MSWI; APC residues; Fly ashes; Heavy metals; Electrodialysis 


\section{Introduction}

Worldwide municipal solid waste generation is expected to double by 2025 [1]. Improving solid waste management is therefore an urgent priority. In many developed countries, a common practice is the incineration of solid waste, as it reduces the volume of waste by up to 90\% [1] and allows energy recovery . Worldwide, approximately 120 million tonnes of waste are incinerated every year [1]. This practice generates fly ashes (FA) and air pollution control (APC) residues, originating from the treatment of the flue gas coming out of the combustion chamber, and constituting 1-5\% of the original waste by mass [2]. FA and APC residues are hazardous and contain several pollutants; among them, salts and heavy metals [3].

Both residues can have different potential applications as substitution of other raw materials in production of construction materials [4]. However, such use is not allowed in some countries like Denmark, where (as in many other western countries) FA and APC residues are normally deposited after treatment [3]. At the same time, huge amounts of virgin resources are used in the construction sector. An upgrade to a higher environmental standard (like a reduced metal and salts leaching), could make them suitable for substitution of raw materials in e.g. concrete production.

Electrodialysis (ED) has been proven a promising technology for this purpose [5, 6]. ED is based on application of an electrical current to a solution or a solid suspension containing ions, forcing cations to move towards the cathode and anions towards the anode. Ion exchange membranes (IEMs), which are able to let chemical species pass depending on their charge, are strategically placed to separate cations and anions from an ion-rich compartment into different compartments. The ED setup used in this work can be seen in Fig. 1.

Previous research has focused on optimising different processing parameters for ED treatment of different materials such as contaminated soils and harbour sediments, municipal solid waste incineration (MSWI) FA/APC residues or sewage sludge ashes; important parameters being the liquid-to-solid ratio (L/S), duration of treatment, current intensity, $\mathrm{pH}$ as well as the number of cell compartments or the use of chemicals like $\mathrm{H}_{2} \mathrm{SO}_{4}$ [7-10]. The performance of different commercial IEMs has been compared in several ED processes like the denitrification of an aqueous solution [11], the removal of organic salts from a fermentation broth [12], as well as the production of acid from waste pickle solutions [13]. Their results show that the transport of the same ion through the different IEMs can vary substantially among the different brands: up to a threefold for $\mathrm{Na}^{+}$and $\mathrm{NO}_{3}^{-}$, up to a 1.3-fold for organic salts, and up to a fourfold for Cl-. Two different ion exchange membrane (IEM) brands have been used in different studies of ED upgrading of MSWI APC 
residues and FA: Ionics $[9,14,15]$ and Neosepta $[5,6,16]$. The influence of the IEM brand used for ED treatment of MSWI residues has, however, never been investigated.

To better understand the influence of the IEM type on upgrading of APC residues and other particular materials by ED, the present work assesses the performance of four IEM trademarks on the ED treatment of MSWI residues. All IEMs were tested for treatment of two common and different waste materials (MSWI FA and APC residues) in order to evaluate if the IEMs differently affect the MSWI residue characteristics after the ED treatment. The overall aim of the investigation was to compare the leachability changes of these residues, induced by the ED treatment, among the four different IEM brands.

\section{Materials and methods}

\subsection{MSWI residues}

Two different Danish MSWI residues were studied:

I. APC residues collected from a semi-dry (SD) flue-gas cleaning system from the MSWI plant REFA I/S. REFA I/S incinerates approximately 120,000 tonnes of household and industrial waste annually. SD were collected on $28^{\text {th }}$ of June 2011 from line 3 after APC additives (slaked lime and activated carbon).

II. FA collected from the electrostatic precipitator in a wet flue-gas cleaning system from the MSWI plant Vestforbrænding I/S, which is the largest plant in Denmark, incinerating approximately 520,000 tonnes of household and industrial waste annually. FA was collected in week 50 in 2011 from the ash silo 5 prior to mixing with the wet scrubber sludge.

After sampling, both residues were dried at $40^{\circ} \mathrm{C}$. They were subsequently dry sieved through a $1 \mathrm{~mm}$ sieve, as performed in previous pilot experiments $[5,6,16]$, to prevent clogging in the flow spacers when scaling up. The removed fraction represented a $1 \%$ of the total initial mass [16].

\subsection{Analytical methods}

Mineralogy, the metal and water soluble salt concentrations and leaching were investigated for both treated and raw MSWI residues after drying them at $105^{\circ} \mathrm{C}$. Water solubility was measured only for the untreated residues. The targeted metals were: Al, As, Ba, Ca, Cd, Cu, Cr (total Cr and $\mathrm{Cr}$ (VI)), Mn, Mo, Na, Ni, Pb, Zn, V, Zn; whereas the target anions were: $\mathrm{Cl}^{-}, \mathrm{SO}_{4}{ }^{2-}$. 
The mineralogy of each residue sample was examined using X-ray powder diffraction (XRPD) with a PANalytical X'Pert PRO. Water solubility was calculated by measuring the weight loss after washing the untreated residues: $100 \mathrm{~g}$ of each residue was shaken with $500 \mathrm{~mL}$ of distilled water for 5 minutes, and thereafter the supernatant was separated and filtered at atmospheric pressure. This procedure was repeated two more times for the same residue before all the suspension was filtered, and dried overnight at $105^{\circ} \mathrm{C}$.The metal content was measured by ICP-OES (Varian 720-ES ICP-OES) in triplicates after pre-treatment by Danish Standard DS259 [17]: $1 \mathrm{~g}$ of each residue and 20mL 7.3 $\mathrm{M} \mathrm{HNO}_{3}$ were heated at $200 \mathrm{kPa}\left(120^{\circ} \mathrm{C}\right)$ for $30 \mathrm{~min}$. The liquid was thereafter separated by vacuum filtration through a $45 \mu \mathrm{m}$ filter and diluted to $100 \mathrm{~mL}$ by de-ionised (DI) water.

The water soluble content of $\mathrm{SO}_{4}{ }^{2-}$ and $\mathrm{Cl}^{-}$was determined on IC (DIONEX DX-120 IC) in triplicates according to DS / EN ISO 10304-2 [18] after water extraction. This was performed as follows: $2.5 \mathrm{~g}$ of each residue and $25 \mathrm{ml}$ distilled water were mixed, shaken for 16 hours on a horizontal shaker operating at 150 rpm, and the extractants were vacuum filtered through $45 \mu \mathrm{m}$ filters.

Leaching experiments were made according to DS/EN 12457-1 [19] in triplicates. The L/S was 2, mixing $40 \mathrm{~g}$ of each residue with $80 \mathrm{~mL}$ DI water. The resulting suspension was shaken at $150 \mathrm{rpm}$ for $24 \mathrm{~h}$ before vacuum filtration through a $45 \mu \mathrm{m}$ filter and the filtrate was divided into two subsamples after measuring the $\mathrm{pH}$ by a Radiometer Analytical $\mathrm{pH}$ electrode. One subsample was used to measure sulphate $\left(\mathrm{SO}_{4}{ }^{2-}\right)$ and chloride $\left(\mathrm{Cl}^{-}\right)$concentrations on ionic chromatograph (IC). The other was diluted at a ratio of 1.25 with concentrated $\mathrm{HNO}_{3}$, and heated at $200 \mathrm{kPa}\left(120^{\circ} \mathrm{C}\right)$ for $30 \mathrm{~min}$, before the metal content analysis on ICP-OES (Varian 720-ES ICP-OES).

\subsection{Experimental set-up}

The Electrodialytic (ED) cell was similar to the ones used in previous experiments [14, 20]. It consisted of four (I, II, III, IV) compartments (Fig. 1) made of cylindrical Plexiglas ${ }^{\circledR}$ with an internal diameter of $8 \mathrm{~cm}$. Compartment III was 10 $\mathrm{cm}$ long and contained in each experiment $35 \mathrm{~g}$ ash and $350 \mathrm{ml}$ of DI water. An electrolyte solution $\left(0.01 \mathrm{M} \mathrm{NaNO}_{3}, \mathrm{pH}\right.$ $<2$ adjusted with $\mathrm{HNO}_{3}$ ) was circulated in each of the electrolyte compartments (I, II and IV) using Totton Pumps NDP 10/2. The electrolyte solution was selected based on positive results from previous researches [14, 20], where no reactions were observed between the electrolyte solution and the transported species (for example, precipitate formation) or the electrodes (for example, gas formation) was observed. This can also allow a more accurate calculation of the mass balances explained in section 2.6. The total volumes used were $500 \mathrm{~mL}$ for I and IV, and $350 \mathrm{~mL}$ for II. A plastic 
strip attached to a glass-stick connected to an overhead stirrer (IKA RW11) was used to stir the ash suspension during remediation. The electrodes were made of platinum coated titanium wire (diameter $3 \mathrm{~mm}$ ) obtained from Permascand®) An Agilent E3612A DC power supply was used to maintain a constant electric dc current. Details on the IEMs used can be found in section 2.4 .

Compartment II was included because a high concentration of soluble salts containing $\mathrm{Cl}^{-}$was expected [3]; otherwise, these anions would enter compartment I, enabling the formation of toxic $\mathrm{Cl}_{2}$ gas from the electrode reaction at the anode: $2 \mathrm{Cl}^{-} \rightarrow \mathrm{Cl}_{2}+2 \mathrm{e}^{-}$

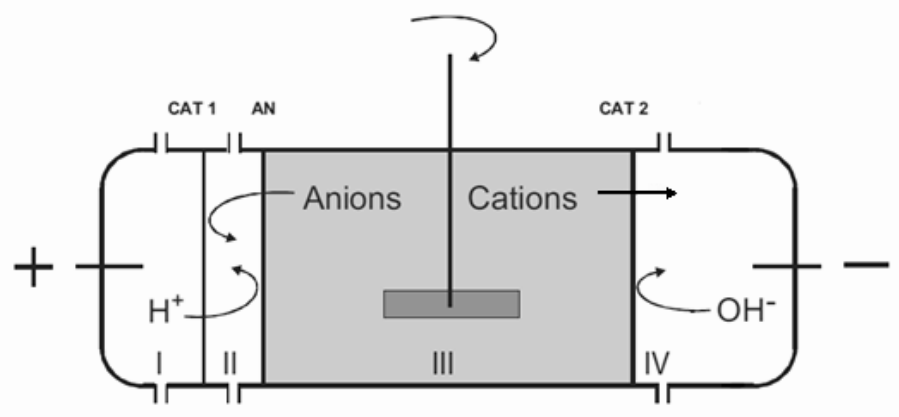

Fig. 1 Schematic view of a cell used for the ED treatment of both APC residues. AN: anion-exchange membrane; CAT1 /CAT2: cation-exchange membranes.

\subsection{Membranes}

Four IEM pairs were selected according to several criteria. The first two trademarks have been used previously in experimental work with ED of MSWI residues:

- Ionics (cationic: CR67-HMR, anionic: AR204-SZRA from GE), from GE Water \& Process Technologies (United States), used in laboratory scale ED cell investigations to reduce the content [14, 21] or the leachability [15] of heavy metals in MSWI residues.

- $\quad$ Neosepta (cationic: CMX, anionic: AMX), from ASTOM Corporation (Japan), used in two pilot scale ED stack investigations to reduce the leachability of heavy metals, chloride and sulphate in MSWI residues $[5,6$, $16]$.

The other two based on their $\mathrm{pH}$ range tolerance (0-14):

- $\quad$ Ralex ${ }^{\circledR}$ (cationic: CM-PP, anionic: AM-PP), from MEGA a.s. (Czech Republic). 
123 The $\mathrm{pH}$ range is a crucial criterion because of the $\mathrm{pH}$ differences between the compartments. MSWI residues, found in

124 compartment III, had a considerable alkalinity $[3,15,16]$. Contrarily, the solutions in the other compartments were kept in an acidic range as explained in the section 2.5 .

Common commercial applications of these IEMs are the deionisation of food products like juices or whey, water and wastewater desalination, as well as electro-coating of automotive parts. Moreover, Ionics membranes have been used in research fields like phosphorus recovery from sewage sludge ashes [10] or heavy metal removal from contaminated soils [22, 23].

\subsection{Experiments}

Combining the two MSWI residues studied and the four IEMs selected, eight different combinations of ED experiments were replicated until enough ED treated material was produced to carry out the analyses described in section 2.2.The duration of the ED treatments was 70 minutes at a current density of $4.67 \mathrm{~mA} / \mathrm{cm}^{2}$. Voltage and current between the two electrodes were monitored during the whole experiment. The $\mathrm{pH}$ (for all compartments) and electrical conductivity (for compartment III) were measured at the beginning, at the end, and every 20 min during the ED treatment. During the experiments, the $\mathrm{pH}$ of the compartment IV (Fig.1 ) was adjusted to $<2.5$ with $\mathrm{HNO}_{3} 1 \mathrm{M}$, to avoid precipitations in the electrolyte due to the production of $\mathrm{OH}^{-}$from electrolysis at the cathode.

Electrolyte samples were taken at the beginning and at the end of all experiments for each compartment in order to study the metal ion mobility among them. At the end of the experiments, the suspension in the central compartment was filtered at atmospheric pressure and dried during 48 hours at $50{ }^{\circ} \mathrm{C}$. The resulting residue was loosened by hand in a mortar and stored in plastic bags under dry conditions. The volumes of the filtered liquid from the middle compartment and the electrolytes were measured. The electrodes were rinsed in $5 \mathrm{~mol} \cdot \mathrm{L}^{-1} \mathrm{HNO}_{3}$, whereas the IEMs and the stirrer in $1 \mathrm{~mol} \cdot \mathrm{L}^{-1} \mathrm{HNO}_{3}$. The samples of compartments III and IV were diluted at a ratio of 1.25 with concentrated $\mathrm{HNO}_{3}$, and heated at $200 \mathrm{kPa}\left(120^{\circ} \mathrm{C}\right)$ for $30 \mathrm{~min}$, prior to the metal content analyses in all liquids on ICP-OES (Varian 720-ES ICP-OES). 
148 Mass balances for each studied metal, defined as the relation between the sum of mass found in the different ED cell 149 compartments at the end of the experiments and the amount initially found in the mass of untreated MSWI residue 150 placed in the ED cell, were made to control the quality of the experiments.

151 An analysis of variances (ANOVA) was run for each element and each treated MSWI residue, so as to evaluate whether the leachability changes after the ED treatment was influenced by the IEM used.

\section{Results and discussion}

\subsection{ED experiments performance}

During the ED remediation with one IEM brand (Excellion), liquid flows between the compartments were observed in all experiments. After contacting the manufacturer, it was determined that the membranes were degraded during the ED experiments due to the use of nitrate solutions in the electrolyte compartments (I, II and IV). Specifically, it was detected that a water permeability as high as $0.01327 \mathrm{~mL} \cdot \mathrm{min}^{-1} \cdot \mathrm{cm}^{-2} \cdot \mathrm{psi}^{-1}$ (the normal value would be below 0.0005 $\left.\mathrm{mL} \cdot \mathrm{min}^{-1} \cdot \mathrm{cm}^{-2} \cdot \mathrm{psi}^{-1}\right)$. Thus, the transport mechanisms of ions between compartments might not be dominated by electromigration, as it can be assumed for the other three IEMs. In consequence, this IEM brand was proven not to be suitable for the present ED remediation of these MSWI residues, and its results are not further analysed. The other IEMs did not present major issues during the experiments.

The mass balances of the studied metals, defined as the recovered amount of an element in percentage of the initial amount, was mainly found in a range of $80-120 \%$. This indicates an acceptable quality of the experiments and the validity of the results presented.

The conductivity in compartment III was stable during the ED experiments (results not shown). For the SD, the values oscillated between 40 and $50 \mathrm{mS} / \mathrm{cm}$, whereas for FA the values oscillated between 25 and $30 \mathrm{mS} / \mathrm{cm}$, with a slight tendency for decrease over the 70-minute experiments for both residues. The higher conductivity in SD than in FA experiments is probably due to a higher presence of leached elements from the residues: water solubility was found to be higher for SD (45.6\%) than FA (12.5\%). Furthermore, water soluble chloride content was almost three times higher 171 in SD than in FA before ED (Table 1). Thus, solubilised anions and cations are likely to be higher in the ED experiments with SD residues. The decrease in the electrical conductivity during the experiments is due to the migration of ions from the suspension into the cathode and the anode compartments. Similar trends were found in previous works 
with APC residues from REFA [5, 6]. As a consequence of the electrical conductivity decrease in compartment III, voltage increased during all experiments by up to $30 \%$. pH in compartment III was stable and between 11 and 12 during ED remediation for both residues, which is due to the high alkalinity of the MSWI residues.

\subsection{MSWI residues characteristics before and after ED treatment}

All XRPD diffractograms showing the mineralogy of the treated and untreated residues had a high background due to the presence of amorphous material in the MSWI residues, as previously seen in other studies [24, 25]. The identified minerals were calcite $\left(\mathrm{CaCO}_{3}\right)$, anhydrite $\left(\mathrm{CaSO}_{4}\right)$, portlandite $\left(\mathrm{Ca}(\mathrm{OH})_{2}\right)$ and Quartz $\left(\mathrm{SiO}_{2}\right)$ for untreated and treated SD. The same minerals phases, except for $\mathrm{SiO}_{2}$, and together with Calcium chloride hydroxide (CaOHCl), Halite ( $\left.\mathrm{NaCl}\right)$ and Sylvite (KCl) were identified for untreated FA. All these phases are consistent with the results from the literature for these two kinds of MSWI residues [24-29]. After ED treatment of FA, two new main phases, (gypsum $\left(\mathrm{CaSO}_{4} \cdot \mathrm{H}_{2} \mathrm{O}\right)$ and $\mathrm{SiO}_{2}$ ) were found, whereas soluble phases like $\mathrm{NaCl}$ and $\mathrm{KCl}$ were not identified. Also, XRD characteristic peaks for $\mathrm{Ca}(\mathrm{OH})_{2}$ had lower intensity for SD and were not detected for FA after the ED experiments; similarly, CaOHCl peaks disappeared after ED treatment of $\mathrm{FA}$. These results indicate that a considerable part of $\mathrm{NaCl}, \mathrm{KCl}, \mathrm{CaOHCl}$ and $\mathrm{Ca}(\mathrm{OH})_{2}$ dissolved during ED. Anhydrite intensity peak increased after all ED treatments, which can be attributed to a higher proportion due to its low solubility and the removal of other compounds.

Table 1 show the metal and the soluble salts content of both MSWI residues before and after ED. Overall, and as seen in a previous study [5], the total concentration of all metals except $\mathrm{Na}$ increased slightly, whereas $\mathrm{Cl}$ and $\mathrm{SO}_{4}$ content were considerably reduced after the ED experiments (Table 1). These facts confirm that water-soluble salts, like $\mathrm{NaCl}$, and $\mathrm{KCl}$ for both residues, and possibly $\mathrm{Na}_{2} \mathrm{SO}_{4}$ for $\mathrm{FA}$, in the untreated residues, were dissolved and removed during ED. Despite their dissolution, $\mathrm{Na}$ as well as the water-soluble part of $\mathrm{Cl}$ and $\mathrm{SO}_{4}$ were, together with $\mathrm{Al}, \mathrm{Ca}, \mathrm{Pb}$ and $\mathrm{Zn}$, the major compounds found for both MSWI residues before and after ED treatment. 
Table 1 Metal and water-soluble salt anion content of SD and FA (mean value \pm standard deviation). The results after ED are calculated as an average of the results of the three IEMs.

\begin{tabular}{ccccc}
\hline \multirow{2}{*}{ Compound (Units) } & \multicolumn{3}{c}{ SD } & \multicolumn{2}{c}{ FA } \\
\cline { 2 - 5 } & Before ED & After ED & Before ED & After ED \\
\hline $\mathrm{Al}(\mathrm{g} / \mathrm{kg})$ & $15.5 \pm 0.09$ & $21.4 \pm 1.11$ & $29.4 \pm 0.36$ & $35 \pm 0.74$ \\
$\mathrm{As}(\mathrm{mg} / \mathrm{kg})$ & $57.7 \pm 2.13$ & $68.4 \pm 5.98$ & $86 \pm 2.19$ & $95.5 \pm 5.02$ \\
$\mathrm{Ba}(\mathrm{mg} / \mathrm{kg})$ & $374 \pm 6.35$ & $409 \pm 24.2$ & $692 \pm 19$ & $797 \pm 49.6$ \\
$\mathrm{Ca}(\mathrm{g} / \mathrm{kg})$ & $296 \pm 3.52$ & $301 \pm 11.7$ & $186 \pm 2.98$ & $198 \pm 5.84$ \\
$\mathrm{Cd}(\mathrm{mg} / \mathrm{kg})$ & $134 \pm 0.78$ & $162 \pm 16.6$ & $95.3 \pm 1.37$ & $107 \pm 4.99$ \\
$\mathrm{Cr}(\mathrm{mg} / \mathrm{kg})$ & $104 \pm 0.87$ & $125 \pm 7.54$ & $97.2 \pm 5.17$ & $109 \pm 4.15$ \\
$\mathrm{Cu}(\mathrm{mg} / \mathrm{kg})$ & $519 \pm 3.94$ & $662 \pm 31.2$ & $712 \pm 5.87$ & $879 \pm 134$ \\
$\mathrm{Mn}(\mathrm{mg} / \mathrm{kg})$ & $352 \pm 10.4$ & $480 \pm 13$ & $649 \pm 10.2$ & $739 \pm 14.2$ \\
$\mathrm{Mo}(\mathrm{mg} / \mathrm{kg})$ & $35.5 \pm 0.49$ & $43.1 \pm 2.05$ & $55.4 \pm 0.87$ & $63.2 \pm 3.05$ \\
$\mathrm{Na}(\mathrm{g} / \mathrm{kg})$ & $32.5 \pm 0.68$ & $5.38 \pm 0.37$ & $34.6 \pm 0.32$ & $5.88 \pm 0.11$ \\
$\mathrm{Ni}(\mathrm{mg} / \mathrm{kg})$ & $27.2 \pm 1.13$ & $33.3 \pm 4.23$ & $48.5 \pm 10.3$ & $47 \pm 3.6$ \\
$\mathrm{~Pb}(\mathrm{~g} / \mathrm{kg})$ & $2.36 \pm 0.03$ & $2.38 \pm 0.14$ & $2.90 \pm 0.05$ & $2.70 \pm 0.09$ \\
$\mathrm{~V}(\mathrm{mg} / \mathrm{kg})$ & $35.1 \pm 0.78$ & $40.7 \pm 2.61$ & $46.2 \pm 3.01$ & $56.7 \pm 6.04$ \\
$\mathrm{Zn}(\mathrm{g} / \mathrm{kg})$ & $15.8 \pm 0.26$ & $21.1 \pm 1.21$ & $20.7 \pm 0.08$ & $23.1 \pm 1.02$ \\
\hline $\mathrm{Cl}(\mathrm{g} / \mathrm{kg})$ & $160 \pm 2.15$ & $15.5 \pm 1.10$ & $60.7 \pm 1.63$ & $2.41 \pm 0.11$ \\
$\mathrm{SO} \mathrm{H}_{4}(\mathrm{~g} / \mathrm{kg})$ & $14.9 \pm 0.03$ & $10.7 \pm 0.37$ & $34.3 \pm 0.98$ & $14.7 \pm 0.35$ \\
\hline & & & & \\
\hline
\end{tabular}




\subsubsection{General behaviour before and after ED treatment}

202 Tables 2 and 3 show the results from the leaching tests. Category 3 values, the Danish guideline levels for water leachable metals and salts for the reuse of residues as in construction materials [30], are also included. MSWI FA/APC residues are generally classified as hazardous and thus these legislation limits would not be applicable, but they can be used as reference to understand the upgrade made after ED experiments.

$\mathrm{Ba}, \mathrm{Pb}$ and $\mathrm{Zn}$ leaching was considerably lower in FA than in SD (Tables 2 and 3), even though their content was similar (Table 1). One reason can be a higher concentration of more alkaline soluble compounds containing either of these elements in SD, such as $\mathrm{PbCl}_{2}, \mathrm{PbO}$ [31], $\mathrm{ZnCl}_{2}$ (previously identified in MSWI residues [26]) or $\mathrm{BaCl}_{2}$. Another explanation can be the lower $\mathrm{pH}$ at the end of the leaching test in FA than in SD (Tables 2 and 3): previous researches showed a lower leaching of $\mathrm{Ba}, \mathrm{Pb}$ and $\mathrm{Zn}$ at $\mathrm{pH} 11$ than at $\mathrm{pH} 12$ in MSWI residues [15, 32-34].

Overall, average leaching for metals and salts was reduced during ED treatment, a tendency also observed in previous researches on ED remediation of FA and APC residues $[5,6,15,16]$. The explanation for this trend can be the dissolution and consequent removal to the electrolyte compartments (I, II and IV in Fig. 1) of the leachable part during the ED treatment. Moreover, ions migration through the IEMs can enhance the dissolution of some compounds by equilibrium displacement. Leaching was reduced, on average, from above to below Category 3 limits for Ba and Na in $\mathrm{SD}$ and for $\mathrm{As}, \mathrm{Na}, \mathrm{Zn}, \mathrm{Cl}, \mathrm{SO}_{4}$ in $\mathrm{FA}$. $\mathrm{Na}$ and $\mathrm{Cl}$ leaching reduction are consistent with the decrease in total concentrations (Table 1). Average leaching values were also reduced from above to below Category 3 limits for As in SD regardless the IEM used, as well as for Pb in FA treated with Ralex IEMs.

219 Notable exceptions were $\mathrm{Cr}$ and $\mathrm{Ni}$ for both SD and FA, as the leaching increased after the ED experiments, in some cases from below to above Category 3 limits (Table 2 and 3). The other exception was $\mathrm{SO}_{4}$ in SD, with a leaching 221 slightly higher after ED treatment. For each element, a separate discussion is needed: of similar FA and APC residues [5, 15, 16]. Cr-solubility in SD and FA has been suggested in other researches to be controlled rather by the presence of sparingly-soluble $\mathrm{Cr}(\mathrm{VI})$ phases, like $\mathrm{BaCrO}_{4}$ and $\mathrm{PbCrO}_{4}$, than by Cr(III) phases [26, 35]. In fact, the solubility of these $\mathrm{Cr}(\mathrm{VI})$ compounds at a high $\mathrm{pH}$ is higher than for $\mathrm{Cr}(\mathrm{III})$. For instance, an alkaline extraction of $\mathrm{PbCrO}_{4}$-spiked soils at $\mathrm{L} / \mathrm{S} 20$ released up to 50,000 $\mu \mathrm{g} \mathrm{Cr} / \mathrm{L}$ [23]; in 
contrast, $\mathrm{Cr}(\mathrm{III})$ solubility at $\mathrm{pH} 12$ is limited to around $10 \mu \mathrm{g} / \mathrm{L}[36]$. The increase in Cr solubilisation after $\mathrm{ED}$ can be due to the removal of soluble $\mathrm{Ba}$ and $\mathrm{Pb}$ compounds, other than chromates: leaching values of $\mathrm{Pb}$ for both residues, and $\mathrm{Ba}$ in $\mathrm{SD}$, were noticeably reduced after $\mathrm{ED}$ treatment (Tables 2 and 3 ). $\mathrm{Ba}$ and $\mathrm{Pb}$ ions

Compared with a previous study on the same MSWI residues [16], the leaching values before the ED treatment were within two standard deviations for all elements, except for Pb in FA which were still in the same order of magnitude (Tables 2 and 3). Leaching values for untreated SD and FA were also in the same order of magnitude for $\mathrm{Cr}, \mathrm{Cu}, \mathrm{Pb}$ and $\mathrm{Zn}$ as another investigation about the same residues [15]. After ED, leaching of most elements were in the range of the results in [16] (in which Neosepta was used) for SD (Table 2), and within two standard deviations for FA (Table 3). Moreover, they had the same order of magnitude for $\mathrm{Cr}, \mathrm{Cu}, \mathrm{Pb}$ and $\mathrm{Zn}$ than the values obtained in [15] with a 3compartment ED cell using Ionics. Therefore, the leaching values before and after ED were in line with previous investigations.

For SD, Category 3 limits were exceeded on average for $\mathrm{Cr}, \mathrm{Pb}, \mathrm{Zn}$ and $\mathrm{Cl}$ after treatment regardless the IEM used and for Ni after treatment using Ionics and Neosepta IEMs (Table 2). The variability of As values was high enough for 
255 Ionics and Neosepta IEMs, so that Category 3 limits could be exceeded or not within one standard deviation (Table 2).

256 For FA, Category 3 limits were exceeded on average for Pb after treatment with Ionics and Neosepta IEMs; remarkably, 257 Category 3 limits were within one standard deviation below the mean value for both IEM (Table 3). Category 3 limits 258 were also slightly exceeded on average for Ni after ED treatment with the three IEMs. It should be noted that there was 259 variability enough for Cr for all IEMs, for Ni with Ralex and for As with Ionics and Ralex to exceed or not Category 3 260 limits within one or two standard deviations (Table 3). Leaching values exceeding Category $3 \mathrm{for} \mathrm{Pb}, \mathrm{Zn}$ and $\mathrm{Cl}$ were 261 observed in a previous work with APC residues from the REFA plant [5]; in that research, the combination of the ED treatment with carbonation was successful in order to reduce the leachability for most of heavy metals except for Cr. A 263 similar treatment could have a potential beneficial effect for the two MSWI residues of this study, although it requires 264 further study.

265 Certified coal fly ash is commonly used in cement production, in contrast to MSWI APC residues, despite that its Cr 266 leaching values normally exceeds Category 3 limits leaching values [38]. In general, considering a range of two standard deviations, ED treated SD and FA have a higher metal leaching than certified coal fly ashes. Exceptions for treated FA were Al, Ba, Ca and Cr, as their leaching in coal fly ashes is higher: 2,600 $\mu \mathrm{g} / \mathrm{L}, 0.7 \mathrm{mg} / \mathrm{L}, 1,200 \mathrm{~g} / \mathrm{L}$ and 1,000 $\mathrm{gg} / \mathrm{L}$ [38], respectively (see Table 3 for comparison). For treated SD, the exceptions were Al and Cr for some IEMs (see Table 2 for comparison). 
Table 2 Metal and salt leaching results from SD according to DS/EN 12457-1 (mean value \pm standard deviation). Average values exceeding Category 3 limits are shown in bold. *Below ICP limit of detection (0.02 mg/L, LOD) ** Range of average values.

\begin{tabular}{|c|c|c|c|c|c|c|c|}
\hline & \multirow{2}{*}{ Before ED } & \multicolumn{3}{|c|}{ After ED } & \multicolumn{2}{|c|}{ Previous research [16] } & \multirow{2}{*}{ Category 3 [28] } \\
\hline & & Ionics & Neosepta & Ralex & Before ED & After ED ** & \\
\hline $\mathrm{pH}$ & $12.3 \pm 0.04$ & $12.1 \pm 0.01$ & $12.1 \pm 0.01$ & $12.1 \pm 0.08$ & 11.9 & $10.2-12.2$ & - \\
\hline As $(\mu \mathrm{g} / \mathrm{L})$ & $91 \pm 15$ & $43 \pm 16$ & $36 \pm 4.2$ & $48 \pm 25$ & $<91$ & $<20-650$ & 50 \\
\hline Ba (mg/L) & $21 \pm 4.4$ & $1.7 \pm 0.14$ & $1.7 \pm 0.08$ & $1.6 \pm 0.14$ & $17 \pm 5$ & $1.6-3.0$ & 4 \\
\hline $\mathrm{Cd}(\mu \mathrm{g} / \mathrm{L})$ & $<20^{*}$ & $<20 *$ & $<20 *$ & $<20 *$ & $<20$ & $<20$ & 40 \\
\hline $\mathrm{Cr}(\mu \mathrm{g} / \mathrm{L})$ & $64 \pm 15$ & $1,200 \pm 45$ & $760 \pm 40$ & $880 \pm 77$ & $61 \pm 2$ & $114-1,015$ & 500 \\
\hline $\mathrm{Cu}(\mu \mathrm{g} / \mathrm{L})$ & $1,200 \pm 1,500$ & $61 \pm 4.0$ & $55 \pm 5.7$ & $240 \pm 15$ & $889 \pm 397$ & $32-141$ & 2,000 \\
\hline $\operatorname{Mn}(\mu \mathrm{g} / \mathrm{L})$ & $100 \pm 160$ & $<20 *$ & $<20 *$ & $<20 *$ & $<100$ & $<20$ & 1,000 \\
\hline $\mathrm{Na}(\mathrm{g} / \mathrm{L})$ & $14 \pm 2.1$ & $1.1 \pm 0.04$ & $1.2 \pm 0.05$ & $1.1 \pm 0.09$ & $13 \pm 2$ & $1.6-7.8$ & 1.5 \\
\hline $\mathrm{Ni}(\mu \mathrm{g} / \mathrm{L})$ & $<20^{*}$ & $110 \pm 13$ & $86 \pm 6.9$ & $56 \pm 5.1$ & $<20$ & $<20-72$ & 70 \\
\hline $\mathrm{Pb}(\mathrm{mg} / \mathrm{L})$ & $570 \pm 77$ & $4 \pm 0.03$ & $3.5 \pm 0.81$ & $14 \pm 1.3$ & $453 \pm 168$ & 1-21 & 0.1 \\
\hline Zn (mg/L) & $39 \pm 3.9$ & $4.5 \pm 0.13$ & $4.4 \pm 0.45$ & $6 \pm 0.41$ & $32 \pm 10$ & $0.1-3.7$ & 1.5 \\
\hline $\mathrm{Al}(\mu \mathrm{g} / \mathrm{L})$ & $930 \pm 120$ & $360 \pm 71$ & $270 \pm 14$ & $220 \pm 280$ & - & - & - \\
\hline $\mathrm{Ca}(\mathrm{g} / \mathrm{L})$ & $32 \pm 4.7$ & $4.8 \pm 0.13$ & $4.9 \pm 0.2$ & $4.7 \pm 0.43$ & - & - & - \\
\hline $\operatorname{Mo}(\mu \mathrm{g} / \mathrm{L})$ & $770 \pm 57$ & $600 \pm 23$ & $600 \pm 16$ & $550 \pm 50$ & 770 & 211-708 & - \\
\hline $\mathrm{V}(\mu \mathrm{g} / \mathrm{L})$ & $<20^{*}$ & $<20^{*}$ & $<20^{*}$ & $<20^{*}$ & $<20$ & $311-662$ & - \\
\hline $\mathrm{Cl}(\mathrm{g} / \mathrm{L})$ & $85 \pm 1.7$ & $8.3 \pm 0.25$ & $8.9 \pm 0.26$ & $8.7 \pm 0.36$ & $87 \pm 3$ & 5.1-35 & 3 \\
\hline $\mathrm{SO}_{4}(\mathrm{~g} / \mathrm{L})$ & $0.87 \pm 0.03$ & $1.3 \pm 0.03$ & $1.3 \pm 0.01$ & $1.3 \pm 0.03$ & $0.9 \pm 0$ & $0.9-1.2$ & 4 \\
\hline
\end{tabular}


Table 3 Metal and salt leaching results from FA according to DS/EN 12457-1 (mean value \pm standard deviation). Average values exceeding Category 3 limits are shown in bold. *Below ICP LOD. ** One of the

$\mathrm{LOD} / 2$.

\begin{tabular}{|c|c|c|c|c|c|c|c|c|}
\hline & \multirow[b]{2}{*}{ Before treatment } & \multicolumn{3}{|c|}{ After treatment } & \multicolumn{3}{|c|}{ Previous research [16] } & \multirow[b]{2}{*}{ Category 3 [28] } \\
\hline & & Ionics & Neosepta & Ralex & Before ED & Afte & ED & \\
\hline $\mathrm{pH}$ & $11.3 \pm 0.24$ & $11.1 \pm 0.01$ & $11.1 \pm 0.01$ & $11.0 \pm 0.03$ & 12.6 & $10.1 \pm 0.1$ & $11.9 \pm 0.4$ & - \\
\hline As $(\mu \mathrm{g} / \mathrm{L})$ & $59 \pm 20$ & $40 \pm 14$ & $36 \pm 2.8$ & $48 \pm 22$ & $<20$ & $<20$ & $<29$ & 50 \\
\hline Ba (mg/L) & $0.46 \pm 0.05$ & $0.29 \pm 0.02$ & $0.3 \pm 0.003$ & $0.22 \pm 0.02$ & $0.4 \pm 0.03$ & $0.8 \pm 0.9$ & $2.6 \pm 0.1$ & 4 \\
\hline $\mathrm{Cd}(\mu \mathrm{g} / \mathrm{L})$ & $<20 *$ & $<20 *$ & $<20 *$ & $<20 *$ & $<20$ & $<20$ & $<20$ & 40 \\
\hline $\mathrm{Cr}(\mu \mathrm{g} / \mathrm{L})$ & $18 \pm 7.5^{* *}$ & $430 \pm 44$ & $480 \pm 49$ & $460 \pm 46$ & $20 \pm 0$ & $991 \pm 234$ & $341 \pm 146$ & 500 \\
\hline $\mathrm{Cu}(\mu \mathrm{g} / \mathrm{L})$ & $30 \pm 6.4$ & $26 \pm 1.7$ & $20 \pm 3$ & $16 \pm 3.5$ & $23 \pm 11$ & $37 \pm 14$ & $28 \pm 25$ & 2,000 \\
\hline $\operatorname{Mn}(\mu \mathrm{g} / \mathrm{L})$ & $<20 *$ & $<20 *$ & $<20 *$ & $<20 *$ & $<20$ & $<20$ & $<20$ & 1,000 \\
\hline $\mathrm{Na}(\mathrm{g} / \mathrm{L})$ & $12 \pm 0.8$ & $0.43 \pm 0.02$ & $0.46 \pm 0.02$ & $0.5 \pm 0.04$ & $14 \pm 2$ & $3.6 \pm 1.1$ & $3.1 \pm 0.6$ & 1.5 \\
\hline $\mathrm{Ni}(\mu \mathrm{g} / \mathrm{L})$ & $<20 *$ & $130 \pm 21$ & $140 \pm 7.7$ & $75 \pm 8.4$ & $<20$ & $<193$ & $<47$ & 70 \\
\hline $\mathrm{Pb}$ (mg/L) & $18 \pm 2.4$ & $0.47 \pm 0.74$ & $0.13 \pm 0.13$ & $0.03 \pm 0.01$ & $40 \pm 2$ & $1.8 \pm 2.2$ & $18 \pm 11$ & 0.1 \\
\hline Zn (mg/L) & $4.5 \pm 0.67$ & $0.57 \pm 0.26$ & $0.46 \pm 0.13$ & $0.27 \pm 0.02$ & $3.3 \pm 1.1$ & $0.2 \pm 0.0$ & $3.5 \pm 2.8$ & 1.5 \\
\hline $\mathrm{Al}(\mu \mathrm{g} / \mathrm{L})$ & $610 \pm 44$ & $1,100 \pm 130$ & $1,000 \pm 96$ & $150 \pm 14$ & - & - & - & - \\
\hline $\mathrm{Ca}(\mathrm{g} / \mathrm{L})$ & $1.4 \pm 0.07$ & $0.97 \pm 0.01$ & $0.98 \pm 0.01$ & $0.93 \pm 0.06$ & - & - & - & - \\
\hline Mo $(\mu \mathrm{g} / \mathrm{L})$ & $2,000 \pm 150$ & $640 \pm 27$ & $660 \pm 14$ & $630 \pm 48$ & $2,024 \pm 48$ & $704 \pm 76$ & $497 \pm 16$ & - \\
\hline $\mathrm{V}(\mu \mathrm{g} / \mathrm{L})$ & $<20 *$ & $<20 *$ & $<20 *$ & $<20 *$ & $4 \pm 55$ & $135 \pm 177$ & $264 \pm 339$ & - \\
\hline $\mathrm{Cl}(\mathrm{g} / \mathrm{L})$ & $31 \pm 0.21$ & $1.4 \pm 0.03$ & $1.4 \pm 0.02$ & $1.6 \pm 0.06$ & $31 \pm 1$ & $14 \pm 11$ & $20 \pm 7$ & 3 \\
\hline $\mathrm{SO}_{4}(\mathrm{~g} / \mathrm{L})$ & $8.4 \pm 0.30$ & $1.6 \pm 0.004$ & $1.7 \pm 0.04$ & $1.8 \pm 0.04$ & $9 \pm 0.5$ & $1.9 \pm 0.4$ & $1.0 \pm 0.4$ & 4 \\
\hline
\end{tabular}


279 The result of the ANOVA among the different ED treatments for each residue with a P-value $>0.05$ showed that mean 280 leaching values were found not to be the same for some of the elements among the three IEMs studied. More 281 specifically, mean leaching values of $\mathrm{Cr}, \mathrm{Cu}, \mathrm{Ni}, \mathrm{Pb}$ and $\mathrm{Zn}$ for the treated $\mathrm{SD}$, and $\mathrm{Ba}, \mathrm{Cu}, \mathrm{Ni}, \mathrm{Al}, \mathrm{Cl}$ and $\mathrm{SO}{ }_{4}$ for the treated FA were found to be different depending on the IEM used. It is worth mentioning that $\mathrm{Pb}$ and $\mathrm{Zn}$ leaching values had a high variability for FA treated with Ionics and Neosepta IEMs (Table 3), which requires further study. The reason could not be the $\mathrm{pH}$ of the different leachates, since they were almost identical regardless the membrane used (Tables 2 and 3).

Main differences were found for $\mathrm{Pb}$ in SD: leaching after ED treatment with Ralex was around 3 to 4 times higher than with the other two IEMs (Table 2). The reason can be a different transportation rate of chloride anions through the IEMs. Ralex IEMs are likely to transport $\mathrm{Cl}^{-}$at a slower rate than Ionics and Neosepta. This can be seen in the water soluble $\mathrm{Cl}$ content for both residues, which was slightly higher after ED treatment with Ralex than with Ionics or Neosepta: 17.0, 15.6 and $15.0 \mathrm{mg} / \mathrm{kg}$ for SD and 2.54, 2.36 and $2.32 \mathrm{mg} / \mathrm{kg}$ for FA, respectively. A slower migration of Cl through Ralex IEMs can entail a lower dissolution of $\mathrm{PbCl}_{2}$ by equilibrium displacement, and, consequently, the content of sparingly soluble $\mathrm{PbCl}_{2}$ in $\mathrm{SD}$ after ED treatment with Ralex can be higher than when using Ionics or Neosepta. However, the transportation of $\mathrm{Cl}^{-}$and the other species through the different IEM brands, and its connection to differences in leachability, require specific research for proper confirmation.

\section{Conclusions}

296 The leaching of some heavy metals and salts in two MSWI residues was found to be different after ED treatment depending on the IEM brand used, without achieving a better overall result for any of them. Further investigation is 298 required in order to understand the unalike transportation of chloride and other ions among different IEMs during ED, and its influence in the leaching behaviour of the hazardous elements from MSWI residues.

ED remediation resulted in the reduction of the leachability for most heavy metals and salts, probably due to the removal of the leachable part. For some metals, like $\mathrm{Al}$ or $\mathrm{Cr}$, the leaching was reduced to below the values found in certified coal fly ash. At the same time, leaching was reduced for some elements like As from above to below the 
MSWI residues had all the leaching values below these levels, and for most elements the final values were higher than for certified coal fly ash.

\section{Acknowledgements}

The Danish Environmental Protection Agency (Ministry of Environment and Food of Denmark) is acknowledged for funding this research as part of the project "Electrodialytic upgrading of MSWI APC residue from hazardous waste to secondary resource".

\section{References}

[1] D. Hoornweg and P. Bhada-Tata, "What a Waste: A Global Review of Solid Waste Management," in "Urban Development Series," 2012.

[2] T. Sabbas et al., "Management of municipal solid waste incineration residues," Waste Management, Article vol. 23, no. 1, pp. 61-88, 2003.

[3] M. J. Quina, J. C. Bordado, and R. M. Quinta-Ferreira, "Treatment and use of air pollution control residues from MSW incineration: An overview," Waste Management, Review vol. 28, no. 11, pp. 2097-2121, Nov 2008.

[4] C. Ferreira, A. Ribeiro, and L. Ottosen, "Possible applications for municipal solid waste fly ash," Journal of Hazardous Materials, Article vol. 96, no. 2-3, pp. 201-216, Jan 2003.

[5] G. M. Kirkelund, P. E. Jensen, A. Villumsen, and L. M. Ottosen, "Test of electrodialytic upgrading of MSWI APC residue in pilot scale: focus on reduced metal and salt leaching," Journal of Applied Electrochemistry, Article; Proceedings Paper vol. 40, no. 6, pp. 1049-1060, Jun 2010.

[6] P. E. Jensen, C. M. D. Ferreira, H. K. Hansen, J. U. Rype, L. M. Ottosen, and A. Villumsen, "Electroremediation of air pollution control residues in a continuous reactor," Journal of Applied Electrochemistry, Article; Proceedings Paper vol. 40, no. 6, pp. 1173-1181, Jun 2010.

[7] P. E. Jensen, L. M. Ottosen, and C. Ferreira, "Electrodialytic remediation of soil fines (\&lt; 63 mu m) in suspension - Influence of current strength and L/S," Electrochimica Acta, Article; Proceedings Paper vol. 52, no. 10, pp. 3412-3419, Feb 2007.

[8] G. M. Nystroem, L. M. Ottosen, and A. Villumsen, "Electrodialytic removal of Cu, Zn, Pb, and Cd from harbor sediment: Influence of changing experimental conditions," Environmental Science \& Technology, Article vol. 39, no. 8, pp. 2906-2911, Apr 2005. 
[9] G. M. Kirkelund, P. E. Jensen, and L. M. Ottosen, "Electrodialytic extraction of heavy metals from greenlandic MSWI Fly Ash as a function of remediation time and L/S ratio," ISCORD 2013: Planning for Sustainable Cold Regions - Proceedings of the 10th International Symposium on Cold Regions Development, pp. 87-96,

[10] P. Guedes, N. Couto, L. M. Ottosen, G. M. Kirkelund, E. Mateus, and A. B. Ribeiro, "Valorisation of ferric sewage sludge ashes: Potential as a phosphorus source," Waste Management , 2016. 
[19] D. Standard, "Characterisation of waste - Leaching - Compliance test for leaching of granular waste materials and sludges - Part 1: One stage batch test at a liquid to solid ratio of $2 \mathrm{l} / \mathrm{kg}$ for materials with high solid content and with particle size below 4 mm (without or with size reduction)," 2002.

[20] C. Ferreira, P. Jensen, L. Ottosen, and A. Ribeiro, "Removal of selected heavy metals from MSW fly ash by the electrodialytic process," Engineering Geology, Article; Proceedings Paper vol. 77, no. 3-4, pp. 339-347, Mar 2005.

[21] A. J. Pedersen, L. M. Ottosen, and A. Villumsen, "Electrodialytic removal of heavy metals from municipal solid waste incineration fly ash using ammonium citrate as assisting agent," Journal of Hazardous Materials, Article vol. 122, no. 1-2, pp. 103-109, Jun 2005.

[22] P. E. Jensen, L. M. Ottosen, and C. Ferreira, "Electrodialytic remediation of soil fines ( $<63 \mathrm{mu} \mathrm{m})$ in suspension - Influence of current strength and L/S," Electrochimica Acta, Article; Proceedings Paper vol. 52, no. 10, pp. 3412-3419, Feb 2007.

[23] R. J. Vitale, G. R. Mussoline, K. A. Rinehimer, J. C. Petura, and B. R. James, "Extraction of sparingly soluble chromate from soils: Evaluation of methods and E(h)-pH effects," Environmental Science and Technology, Environ. Sci. Technol, Env Sci Tec, Environ Sci Technol, Environmental Science and Technology, vol. 31, no. 2, pp. 390-394, 1997.

[24] T. T. Eighmy et al., "COMPREHENSIVE APPROACH TOWARD UNDERSTANDING ELEMENT SPECIATION AND LEACHING BEHAVIOR IN MUNICIPAL SOLID-WASTE INCINERATION ELECTROSTATIC PRECIPITATOR ASH," Environmental Science \& Technology, Article vol. 29, no. 3, pp. 629-646, Mar 1995.

[25] A. J. Pedersen, "Electrodialytic Removal of Heavy Metals from Fly Ashes (PhD thesis)," Technical University of Denmark (DTU), 2002.

[26] M. J. Quina, R. C. Santos, J. C. Bordado, and R. M. Quinta-Ferreira, "Characterization of air pollution control residues produced in a municipal solid waste incinerator in Portugal," Journal of Hazardous Materials, Article vol. 152, no. 2, pp. 853-869, Apr 2008.

[27] C. S. Kirby and J. D. Rimstidt, "MINERALOGY AND SURFACE-PROPERTIES OF MUNICIPAL SOLIDWASTE ASH," Environmental Science \& Technology, Article vol. 27, no. 4, pp. 652-660, Apr 1993.

P. Fermo et al., "The analytical characterization of municipal solid waste incinerator fly ash: methods and preliminary results," Fresenius Journal of Analytical Chemistry, Article vol. 365, no. 8, pp. 666-673, Dec 1999. 
[29] A. T. Lima, L. M. Ottosen, A. J. Pedersen, and A. B. Ribeiro, "Characterization of fly ash from bio and municipal waste," Biomass \& Bioenergy, Article vol. 32, no. 3, pp. 277-282, Mar 2008.

D. M. o. Environment, "Bekendtgørelse om anvendelse af restprodukter og jord til bygge- og anlægsarbejder og om anvendelse af sorteret, uforurenet bygge- og anlægsaffald BEK nr 1662 af 21/12/2010 (in Danish)," 2010.

[31] S. Nagib and K. Inoue, "Recovery of lead and zinc from fly ash generated from municipal incineration plants by means of acid and/or alkaline leaching," Hydrometallurgy, Hydrometallurgy, Hydrometall, Hydrometallurgy, vol. 56, no. 3, pp. 269-292, 2000.

[33] T. Astrup, H. Mosbæk, and T. H. Christensen, "Assessment of long-term leaching from waste incineration airpollution-control residues," Waste Management, vol. 26, no. 8, pp. 803-814, 2006.

[35] M. Van Praagh and K. M. Persson, "Metal releases from a municipal solid waste incineration air pollution control residue mixed with compost," Waste Management \& Research, vol. 26, no. 4, pp. 377-388, Aug 2008. Total Environment, vol. 86, no. 1-2, pp. 15-23, 1989.

[37] A. M. Scheidegger, E. Wieland, A. C. Scheinost, R. Dahn, and P. Spieler, "Spectroscopic evidence for the formation of layered Ni-Al double hydroxides in cement," Environmental Science \& Technology, vol. 34, no. 21, pp. 4545-4548, Nov 2000. 